\title{
Effect of Pre-Grafting Incubation and Grafted Cuttings Positionon Grape Grafting Success
}

\author{
A. A. Rashedy \\ Pomology Department, Faculty of Agriculture, Cairo University, \\ Cairo, Egypt.
}

\begin{abstract}
7 HIS EXPREMENTS was carried out during two successive seasons 2015 and 2016 at the nursery of pomology department, Faculty of Agriculture, Cairo university, Egypt. The study was aimed to investigate the effect of two fators namely i.e, pre-grafting incubation and grafting materials position during callusing on grafting success of flame seedless grapes onto Salt Creek rootstock. Callusing was carried out in three positions i.e, horizontal, upright and upright down either with or without pre-grafting incubation. The results showed that either pre-grafting incubation or callusing at uprightposition increased significantly callus percent and degree, sucker number, rooting rate, bud break percent during callusing period and grafting success percent. The interaction, betweentreatments revealed thatcallusing at uprightpositionaccompanied with pregrafting incubation gave the best results in this respect. It can be concluded that callusing at uprightposition either with or without pregrafting incubation increased grafting success significantly compared to callusing at horizontal or upright down position.Chemically, higher grafting success is accompanied with lower phenols, reducing sugars and total indoles. It may be concluded that there is no antagonistic effect between root and callusformation in grafted cuttings. Also, upright position for incubation the grafted cuttings are better than pregrafted incubation in increasing grape grafted cuttings.
\end{abstract}

Keywords: Callus, Propagation, Vitis.

Grapevine (Vitis vinifera) is one of the most popular fruit in Egypt with total harvested area of 64,253 Haand a total production 21.62 ton/ha (FAO, 2016). Forsafety agriculture Flame seedless, one of the most exported grapevariety in Egypt due to early and high production (Hegazi and Omar, 2000 and Diab et al., 2009), is. Grafted on rootstocks like Salt Creek with boths nematodes resistance (Mckenry and Anwar, 2006) and salt tolerance (Walker et al., 1997).

It has recently demosntrated that bench grafting technique by using directly recently dormant wood of both scion and rootstocksreduce the time for transplants production to only 4 months (Halbrooks, 1985). This technique with increasing grafting success percent led to lowering the costs for transplants production. So, the grafted cutting needs to formation rooting and grafting union together, which needs for more care. So, Preparing grafts material prior tografting $\mathrm{n}$ either by storing it in cold environment in moist sawdust (Porebski 
et al., 2002), or storing it at low temperature before grafting (Ferhato1997, Achim and Botu, 2001), or forcing it at 26 to $28^{\circ} \mathrm{C}$ for $2-3$ days (Lantos, 1990 and Ozkanand Gumús, 2001) or finally, soaking scion wood in running water for several hours (Erdogan, 2006 and Halbrooks, 1985), has a vital role for callus formatio position. While in grafted walnut seedling should be placed uprightly (Zachej, 1976). in Egypt, many nursery prefer to callusing their grafts cuttings in a horizontal position to avoid more rooting and to be easier for planting in pots.

There are many factors involved in the grafting success such as the rooting ability of the rootstock, type of graft, fungal infection of cut surfaces and particularly callus formation (Halbrooks, 1985). Callus formation is a key factor in the development of the graft union and subsequent grafting success (Phillips et al., 2015). Carbohydrates, plant hormones (Vrsic et al., 2015 and Hartmann et al., 2002), low amount of phenols and high amount of indoles are required for grafted material at grafting unionearly for successful callus formation to ensure grape grafting success (Stino et al., 2011). Moreover, degree of grapes incompatibility are not well known and are often ascribed to inability for callusing, root formation, budding, and growth during callusing (Hunter et al., 2004).

In order to know how pre-grafting incubation and grafting material position during callusingaffecting callus formation and grafting success the following experiment was done

\section{Materials and Methods}

The exprement was carried out during two successive seasons 2015 and 2016 at the nursery of the Pomology Department, Faculty of Agriculture, Cairo university, Egypton 'Flame seedles's (Vitis vinifea) grapevines grated into Salt creek (Vitis champanii) rootstock. Position Dormant cuttings of the scion and rootstock were taken at January in both years and stored at $5{ }^{\circ} \mathrm{C} . \mathrm{t}$ mid of FebruaryScions were cut to leave one bud, while rootstocks were cut to leave three ones.The treatments includedcallusing after grafting in three positions: horizental, upright and upright down with or without pre-grafting horizontal incubationat $27^{\circ} \mathrm{C}$ for one week. Bench graft technique consisted of cleft grafting using parafin wax after wrapping, then placed into callusing boxes containing peat: sawdust mixture $\left(1: 4\right.$ ratio) at $27^{\circ} \mathrm{C}$ and relative humidity up to $90 \%$ for 4 weeks.After incubation grafts were planted out in greenhouse.with 75 grafting material plantsin three replicates were used for each of the six treatments.

At the end of callusing period, the percent of callused grafts (number of callusedgrafts/ total number of grafted cuttings), callusing degreeusing scale 0,1 , 2,3 and 4 for callusing percent at grafting point ,i.e. no callusing, 1-25\%, 26$50 \%, 51-75 \%$ and 76-100\%, respectively (Kose and Guleryuz, 2006 and Paunovic et al.,2011). Sucker number were counted and then removed, bud break percent (total number of breaked scion bud /total number of grafts), root

Egypt. J. Hort. Vol. 43, No. 2 (2013) 
weight $(\mathrm{g})$ and rooting rate (number of rooted grafts/ total number of grafted plants) were determined according to Kamilogluand Tangolar (1997). After two monthsof growth under green house suckers numberwerecounted then removed weekly, percent of grafting success (number of successed grafts / total number of grafts cuttings) and plant weight (gm) were determined.

Chemical analysis includes total indoles content according to Larsen et al. (1962), total phenols acording to Singleton et al. (1999) and reducing sugars according to Dubois et al. (1956) in one gram fresh weight of scion and rootstock buds immediately after fnishing thecallusing period.

position.Data were analyzed of variance (ANOVA) according to Snedecor and Cochran (1989) using MSTAT-C statistical package (Freed et al., 1990) software, and means of the treatments were compared by Least Significant Difference (L.S.D.) according to Duncan (1955) at significance level of 0.05.

\section{Callus percent}

\section{Results}

Concerning the effect of pre-grafting incubation on callus percent the data in table 1 indicated that pre-grafting incubation increased it in both seasons with a significant value in the first one.

With regard to the effect of position of grafting material in incubation room on plant callus formation percent, the data indicated that incubation of grafted plant materials in upright direction increased it in the two seasons beside horizontal position in the second season with a significant effect than upright down position.

With respect to the interaction, it is cleared that pre-grafted incubation accompanied with upright position recorded the highest significant callusing percent, followed by pre-grafting incubation in horizontal position.

TABLE 1. Effect of pre-grafting incubation and position of grafted materials during callusing on callus percent of grafted 'Flame seedless' grapevines.

\begin{tabular}{|l|c|c|c|c|}
\hline \multirow{2}{*}{ pre-grafting } & \multicolumn{5}{|c|}{ position during callusing 2015 } & \multirow{2}{*}{ Mean } \\
\cline { 2 - 4 } & Horizontal & Upright & Upright down & \\
\hline no incubation & $83.80 \mathrm{c}$ & $90.40 \mathrm{~b}$ & $53.47 \mathrm{~d}$ & 75.889 \\
\hline incubation & $91.67 \mathrm{~b}$ & $95.40 \mathrm{a}$ & $89.33 \mathrm{~b}$ & $* 92.133$ \\
\hline Mean & $87.73 \mathrm{~B}$ & $92.90 \mathrm{~A}$ & $71.40 \mathrm{C}$ & \\
\hline \multicolumn{5}{|c|}{2016} \\
\hline no incubation & $92.13 \mathrm{~b}$ & $87.07 \mathrm{c}$ & $71.80 \mathrm{~d}$ & 83.667 \\
\hline incubation & $94.47 \mathrm{~b}$ & $99.00 \mathrm{a}$ & $91.67 \mathrm{~b}$ & 95.044 \\
\hline Mean & $93.30 \mathrm{~A}$ & $93.03 \mathrm{~A}$ & $81.73 \mathrm{~B}$ & \\
\hline
\end{tabular}

Egypt. J. Hort. Vol. 43, No. 2 (2016) 


\section{Callus degree}

Concerning the effect of pre-grafting incubation on callus degree the data in Table 2 indicated that, pre-grafting incubation increased it significantlyin both seasons. With regard to the effect of grafting material position, the data indicated that incubation of grafted plant material in upright position increased it significantly in the two seasons compared to the other treatments.

TABLE 2. Effect of pre-grafting incubation and grafted material position during callusing on callus degree of grafted 'Flame seedless' grapevines.

\begin{tabular}{|l|c|c|c|c|}
\hline \multirow{2}{*}{ pre-grafting } & \multicolumn{5}{|c|}{ position during callusing 2015 } & \multirow{2}{*}{ Mean } \\
\cline { 2 - 5 } & Horizontal & Upright & Upright down & \\
\hline no incubation & $1.400 \mathrm{e}$ & $2.520 \mathrm{~b}$ & $1.617 \mathrm{~d}$ & 1.846 \\
\hline incubation & $1.317 \mathrm{f}$ & $2.817 \mathrm{a}$ & $2.403 \mathrm{c}$ & $* * 2.179$ \\
\hline Mean & $1.358 \mathrm{C}$ & $2.668 \mathrm{~A}$ & $2.010 \mathrm{~B}$ & \\
\hline \multicolumn{7}{|c|}{} \\
\hline no incubation & $2.000 \mathrm{c}$ & $1.600 \mathrm{~d}$ & $1.000 \mathrm{e}$ & 1.533 \\
\hline incubation & $2.333 \mathrm{~b}$ & $3.533 \mathrm{a}$ & $2.400 \mathrm{~b}$ & $* 2.756$ \\
\hline Mean & $2.167 \mathrm{~B}$ & $2.567 \mathrm{~A}$ & $1.700 \mathrm{C}$ & \\
\hline
\end{tabular}

With respect to the interaction, it is cleared that pre-grafted incubation accompanied with upright incubation callus degree recorded the highest significant treatments.

\section{Sucker number aftercallusing}

The effect of pre-grafting incubation at $27 \mathrm{C}$ on total sucker number after callusing is presented in Table 3. It indicates that this treatment increased it significantly in both seasons.

With regard to the effect of grafting material position during callusing, the data indicated that incubation of grafted plant material in upright position increased sucker numbers with a significant effect in the two seasons compared to the other two positions.

With respect to the interaction, it is cleared that pre-grafted incubation combined with upright position recorded the highest significant sucker numbers followed by upright incubation position with no pre-grafting incubation.

\section{Rooting rate percent}

The data in Table 4 show the effect of pre-grafting incubation on rooting rate. Pre-grafting incubation increased rooting rate with a high significant values in both seasons.

With regard to the effect of grafting material position, the data indicated that incubation of grafted plant material in upright position increased rooting rate in the two seasons with a significant effect than the other positions.

Egypt. J. Hort. Vol. 43, No. 2 (2013) 
EFFECT OF PRE-GRAFTING INCUBATION AND GRAFTED...

TABLE 3. Effect of pre-grafting incubation and grafted material position on suker number of grafted flame seedless grapevines after callusing.

\begin{tabular}{|c|c|c|c|c|}
\hline \multirow{2}{*}{ pre-grafting } & \multicolumn{3}{|c|}{ position during callusing 2015} & \multirow{2}{*}{ Mean } \\
\hline & Horizontal & Upright & Upright down & \\
\hline no incubation & $7.000 \mathrm{~d}$ & $12.06 \mathrm{~b}$ & $5.443 \mathrm{e}$ & 8.167 \\
\hline incubation & $8.443 \mathrm{c}$ & $15.56 \mathrm{a}$ & $8.557 \mathrm{c}$ & $* 10.852$ \\
\hline Mean & $7.722 \mathrm{~B}$ & $13.81 \mathrm{~A}$ & $7.000 \mathrm{C}$ & \\
\hline \multicolumn{5}{|c|}{2016} \\
\hline no incubation & $1.490 \mathrm{~d}$ & $5.443 \mathrm{~b}$ & $0.4333 \mathrm{e}$ & 2.456 \\
\hline incubation & $3.057 \mathrm{c}$ & $9.943 \mathrm{a}$ & $2.443 \mathrm{c}$ & $* * 5.148$ \\
\hline Mean & $2.273 \mathrm{~B}$ & $7.693 \mathrm{~A}$ & $1.438 \mathrm{C}$ & \\
\hline
\end{tabular}

Values of the interaction cleared that pre-grafted incubation accompanied with upright and upright down in the two seasons besides up right position with or without incubation in the second season recorded the highest significant values compared to the other treatments.

TABLE 4. Effect of pre-grafting incubation and grafted material position on rooting rate percent of grafted 'Flame seedless' grapevines after callusing.

\begin{tabular}{|l|c|c|c|c|}
\hline \multirow{2}{*}{ pre-grafting } & \multicolumn{5}{|c|}{ position during callusing 2015 } & \multirow{2}{*}{ Mean } \\
\cline { 2 - 5 } & Horizontal & Upright & Upright down & \\
\hline no incubation & $74.80 \mathrm{c}$ & $85.27 \mathrm{~b}$ & $47.07 \mathrm{~d}$ & 69.044 \\
\hline incubation & $84.33 \mathrm{~b}$ & $99.33 \mathrm{a}$ & $95.73 \mathrm{a}$ & $* * 93.133$ \\
\hline Mean & $79.57 \mathrm{~B}$ & $92.30 \mathrm{~A}$ & $71.40 \mathrm{C}$ & \\
\hline \multicolumn{7}{|c|}{} \\
\hline no incubation & $81.47 \mathrm{c}$ & $93.07 \mathrm{a}$ & $57.00 \mathrm{~d}$ & 77.178 \\
\hline incubation & $79.13 \mathrm{c}$ & $93.67 \mathrm{a}$ & $87.20 \mathrm{~b}$ & $* 86.667$ \\
\hline Mean & $80.30 \mathrm{~B}$ & $93.37 \mathrm{~A}$ & $72.10 \mathrm{C}$ & \\
\hline
\end{tabular}

\section{Root weight}

The effect of pre-grafting incubation on root weight after callusing is presented in Table 5. It indicated that pre-grafting incubation increased root weight with a significant value in the first season.

With regard to the effect of grafting material position, the data indicated that incubation of grafted plant material in upright position and in horizontal position significantly increased root weight in the first and second season, respectively.

Values of the interaction cleared that pre-grafted incubation accompanied with upright position and horizontal position in the first and second season, respectively recorded the highest significant values compared to the other treatments. 
TABLE 5. Effect of pre-grafting incubation and grafted material position on root weight 4of grafted 'Flame seedless' grapevines after callusing.

\begin{tabular}{|c|c|c|c|c|}
\hline \multirow{3}{*}{ pre-grafting } & \\
\hline & \multicolumn{3}{|c|}{ position during callusing 2015} & \multirow{2}{*}{ Mean } \\
\hline & Horizontal & Upright & Upright down & \\
\hline no incubation & $1.700 \mathrm{de}$ & $1.967 \mathrm{bc}$ & $1.567 \mathrm{e}$ & 1.744 \\
\hline incubation & $2.133 \mathrm{~b}$ & $2.400 \mathrm{a}$ & $1.800 \mathrm{~cd}$ & $* 2.111$ \\
\hline Mean & $1.917 \mathrm{~B}$ & $2.183 \mathrm{~A}$ & $1.683 \mathrm{C}$ & \\
\hline \multicolumn{5}{|c|}{2016} \\
\hline no incubation & $2.607 \mathrm{~b}$ & $2.120 \mathrm{c}$ & $0.4533 \quad \mathrm{f}$ & 1.727 \\
\hline incubation & $2.913 \mathrm{a}$ & $1.253 \mathrm{~d}$ & $0.8600 \quad \mathrm{e}$ & 1.676 \\
\hline Mean & $2.760 \mathrm{~A}$ & $1.687 \mathrm{~B}$ & $0.6567 \mathrm{C}$ & \\
\hline
\end{tabular}

\section{Bud break percent}

Data in Table 6 indicated that pre-grafting incubation increased the scion bud break percent significantly in both seasons.

TABLE 6. Effect of pre-grafting incubation and grafted material position on scion bud break percent of grafted 'Flame seedless' grapevines after callusing.

\begin{tabular}{|l|c|c|c|c|}
\hline \multirow{2}{*}{ pre-grafting } & \multicolumn{5}{|c|}{ position during callusing 2015 } & \multirow{2}{*}{ Mean } \\
\cline { 2 - 5 } & Horizontal & Upright & Upright down & \\
\hline no incubation & $22.27 \mathrm{~d}$ & $32.40 \mathrm{c}$ & $18.00 \mathrm{e}$ & 24.222 \\
\hline incubation & $36.67 \mathrm{~b}$ & $74.20 \mathrm{a}$ & $9.867 \quad \mathrm{f}$ & $* * 40.244$ \\
\hline Mean & $29.47 \mathrm{~B}$ & $53.30 \mathrm{~A}$ & $13.93 \mathrm{C}$ & \\
\hline \multicolumn{5}{|c|}{} \\
\hline no incubation & $32.73 \mathrm{~b}$ & $31.53 \mathrm{~b}$ & $7.167 \mathrm{~d}$ & 23.809 \\
\hline incubation & $33.40 \mathrm{~b}$ & $64.57 \mathrm{a}$ & $11.20 \mathrm{c}$ & $* * 36.389$ \\
\hline Mean & $33.07 \mathrm{~B}$ & $48.05 \mathrm{~A}$ & $9.183 \mathrm{C}$ & \\
\hline
\end{tabular}

With regard to the effect of grafting material position, the data indicated that incubation of grafted plant material in upright position increased significantly the bud break percent followed by horizontal then upright down position in both seasons.

With respect to the interaction, it is cleared that pre-grafted incubation accompanied with upright incubation position recorded the highest significant percentage of bud break followed by horizontal position with pre-grafted incubation.

\section{Sucker number after planting}

The effect of pre-grafting incubation on sucker number after planting is shown in Table 7. The data indicated that pre-grafting incubation increased sucker number with a significant value in the second season.

Egypt. J. Hort. Vol. 43, No. 2 (2013) 
With regard to the effect of grafting material position, the data indicated that incubation of grafted plant material in upright down position increased sucker number in the two seasons with a significant effect than the other two positions.

As for the interaction, it is cleared that pre-grafted incubation accompanied with upright down position recorded the highest significant values in the first season.

TABLE 7. Effect of pre-grafting incubation and grafted material position on sucker number of grafted Flame seedless' grapevines after planting.

\begin{tabular}{|l|c|c|c|c|}
\hline \multirow{2}{*}{ pre-grafting } & \multicolumn{3}{|c|}{ position during callusing 2015 } & \multirow{2}{*}{ Mean } \\
\cline { 2 - 4 } & Horizontal & Upright & Upright down & \\
\hline no incubation & $8.277 \mathrm{e}$ & $16.94 \mathrm{~b}$ & $10.98 \mathrm{~d}$ & 12.066 \\
\hline incubation & $7.557 \mathrm{e}$ & $12.04 \mathrm{c}$ & $20.44 \mathrm{a}$ & 13.348 \\
\hline Mean & $7.917 \mathrm{C}$ & $14.49 \mathrm{~B}$ & $15.71 \mathrm{~A}$ & \\
\hline \multicolumn{5}{|c|}{2016} \\
\hline no incubation & $21.89 \mathrm{~d}$ & $19.89 \mathrm{e}$ & $19.44 \mathrm{f}$ & 20.408 \\
\hline incubation & $26.89 \mathrm{~b}$ & $24.89 \mathrm{c}$ & $34.55 \mathrm{a}$ & $* * 28.778$ \\
\hline Mean & $24.39 \mathrm{~B}$ & $22.39 \mathrm{C}$ & $27.00 \mathrm{~A}$ & \\
\hline
\end{tabular}

Plant weight

Concerning the effect of pre-grafting incubation on plant weight, the data in Table 8 indicated that pre-grafting incubation increased it with a significant value in the first seasons.

As for the effect of grafting material position, the data indicated that incubation of grafted plant material in upright position increased it significantly in both seasons compared to the other positions.

With respect to the interaction, it is cleared that pre-grafted incubation accompanied with upright incubation position recorded the highest significant values followed by upright position with no pre-grafting incubation.

TABLE 8. Effect of pre-grafting incubation and grafted material position on plant weight of grafted 'Flame seedless' grapevines.

\begin{tabular}{|l|c|c|c|c|}
\hline \multirow{2}{*}{ pre-grafting } & \multicolumn{3}{|c|}{ position during callusing 2015} & \multirow{2}{*}{ Mean } \\
\cline { 2 - 4 } & Horizontal & Upright & Upright down & \multirow{2}{*}{$* 24.046$} \\
\hline no incubation & $23.44 \mathrm{~cd}$ & $27.27 \mathrm{~b}$ & $21.42 \mathrm{~d}$ & 25.919 \\
\hline incubation & $24.13 \mathrm{c}$ & $31.33 \mathrm{a}$ & $22.30 \mathrm{~cd}$ & \\
\hline Mean & $23.78 \mathrm{~B}$ & $29.30 \mathrm{~A}$ & $21.86 \mathrm{C}$ & \\
\hline \multicolumn{5}{|l}{} \\
\hline no incubation & $23.38 \mathrm{c}$ & $34.56 \mathrm{a}$ & $28.35 \mathrm{~b}$ & 28.763 \\
\hline incubation & $25.07 \mathrm{c}$ & $34.67 \mathrm{a}$ & $29.86 \mathrm{~b}$ & 29.863 \\
\hline Mean & $24.22 \mathrm{C}$ & $34.61 \mathrm{~A}$ & $29.10-\mathrm{B}$ & \\
\hline
\end{tabular}

Egypt. J. Hort. Vol. 43, No. 2 (2016) 
Grafting successpercent

Concerning the effect of pre-grafting incubation on grafting success, the data in Table 9 indicated that pre-grafting incubation increased it significantly in both seasons.

TABLE 9. Effect of pre-grafting incubation and grafted material position on grafting success of grafted 'Flame seedless' grapevines.

\begin{tabular}{|l|c|c|c|c|}
\hline \multirow{2}{*}{ pre-grafting } & \multicolumn{3}{|c|}{ position during callusing 2015 } & \multirow{2}{*}{ Mean } \\
\cline { 2 - 4 } & Horizontal & Upright & Upright down & \\
\hline no incubation & $45.12 \mathrm{~d}$ & $70.50 \mathrm{a}$ & $37.60 \mathrm{e}$ & 51.073 \\
\hline incubation & $67.93 \mathrm{~b}$ & $70.58 \mathrm{a}$ & $48.28 \mathrm{c}$ & $* * 62.266$ \\
\hline Mean & $56.53 \mathrm{~B}$ & $70.54 \mathrm{~A}$ & $42.94 \mathrm{C}$ & \\
\hline \multicolumn{5}{|l}{} \\
\hline no incubation & $59.00 \mathrm{~b}$ & $70.53 \mathrm{a}$ & $50.27 \mathrm{c}$ & 59.933 \\
\hline incubation & $69.27 \mathrm{a}$ & $70.93 \mathrm{a}$ & $57.07 \mathrm{~b}$ & $* * 65.756$ \\
\hline Mean & $64.13 \mathrm{~B}$ & $70.73 \mathrm{~A}$ & $53.67 \mathrm{C}$ & \\
\hline
\end{tabular}

With regard to the effect of grafting material position, the data indicated that incubation of grafted plant material in upright position increased the success of grafts highly significant in both seasons compared to the other positions.

The interaction cleared that, upright incubation position recorded the highest significant values either with or without pre-grafting incubation in both seasons as well as pre-grafted in horizontal position with pre-grafting incubation in the second season.

\section{Total indoles content}

From the data shown in table 10 it can be found that, generally,scion contain more total indoles than rootstock. Also, incubation pre-grafting decreased significantly indoles content in rootstocks.

With regard to the effect of grafts position it can be found that, upright position during callusing recorded the highest total indoles in scion and rootstock beside the scion in horizontal positions.

With respect to the interaction the data showed that upright position recorded the highest indoles content, while horizontal accompanied with pre-grafting incubation recorded the lowest content.

\section{Total phenols content}

The effect of pre-grafting incubation and scion position during callusing on total phenols is shown in Table11. Pre-grafting incubation increased significantly phenols content especially in rootstock. It can be observed that scion contain more phenols than rootstock.

Egypt. J. Hort. Vol. 43, No. 2 (2013) 
EFFECT OF PRE-GRAFTING INCUBATION AND GRAFTED...

TABLE 10. Effect of pre-grafting incubation and position of grafted materials after callusing on total indole content of grafted 'Flame seedless' grapevines.

\begin{tabular}{|c|c|c|c|c|}
\hline \multirow{3}{*}{ pre-grafting } & \multirow{2}{*}{\multicolumn{3}{|c|}{ Flame seedless scion $\mathrm{mg} / \mathrm{L}$ FW }} & \multirow{3}{*}{ Mean } \\
\hline & & & & \\
\hline & Horizontal & Upright & Upright down & \\
\hline no incubation & $5.617 \mathrm{ab}$ & $4.127 \mathrm{bc}$ & $7.630 \mathrm{a}$ & 5.791 \\
\hline incubation & $4.853 \mathrm{bc}$ & $2.393 \mathrm{c}$ & $4.300 \mathrm{bc}$ & n.s.3.849 \\
\hline Mean & $5.235 \mathrm{~A}$ & $3.260 \mathrm{~B}$ & $5.965 \mathrm{~A}$ & \\
\hline \multicolumn{5}{|c|}{ Salt Creek rootstock } \\
\hline no incubation & $2.117 \mathrm{~b}$ & $2.080 \mathrm{~b}$ & $8.080 \mathrm{a}$ & $* 4.092$ \\
\hline incubation & $3.053 \mathrm{~b}$ & $3.157 \mathrm{~b}$ & $1.283 \mathrm{~b}$ & 2.498 \\
\hline Mean & $2.585 \mathrm{~B}$ & $2.618 \mathrm{~B}$ & $4.682 \mathrm{~A}$ & \\
\hline
\end{tabular}

With regard to the effect of grafts position, it can be found that, upright position during callusing recorded the highest total phenols either in scion or rootstock beside the rootstock in horizontal positions, while the upright positions recorded the lowest content.

With respect to the interaction the data showed that upright position recorded the highest scion and rootstock indoles beside horizontal rootstock a combined with pre-grafting incubation.

TABLE 11. Effect of pre-grafting incubation and position of grafted materials after callusing on total phenols content of grafted 'Flame seedless' grapevines.

\begin{tabular}{|l|c|c|c|c|}
\hline \multirow{2}{*}{ pre-grafting } & \multicolumn{3}{|c|}{ Flame seedless scion mg/L FW } & \multirow{2}{*}{ Mean } \\
\cline { 2 - 4 } & Horizontal & Upright & Upright down & \\
\hline no incubation & $43.35 \mathrm{~cd}$ & $39.32 \mathrm{~d}$ & $48.69 \mathrm{abc}$ & 43.788 \\
\hline incubation & $46.79 \mathrm{bc}$ & $51.05 \mathrm{ab}$ & $53.81 \mathrm{a}$ & $* 50.55$ \\
\hline Mean & $45.07 \mathrm{~B}$ & $45.18 \mathrm{~B}$ & $51.25 \mathrm{~A}$ & \\
\hline \multicolumn{5}{|c|}{ Salt creek rootstock } \\
\hline no incubation & $25.16 \mathrm{~b}$ & $27.14 \mathrm{~b}$ & $34.91 \mathrm{~b}$ & 29.071 \\
\hline incubation & $34.52 \mathrm{~b}$ & $50.47 \mathrm{a}$ & $56.83 \mathrm{a}$ & $* * 47.274$ \\
\hline Mean & $29.84 \mathrm{~B}$ & $38.81 \mathrm{AB}$ & $45.87 \mathrm{~A}$ & \\
\hline
\end{tabular}

Reducing sugars content

The effect of pre-grafting incubation and scion position during callusing on reducing sugars content shown in Table 12. Pre-grafting incubation increased reducing sugars content highly significant in rootstock. It can be observed that scion contain more reducing sugars content than rootstocks.

With regard to the effect of grafts position, it can be found that, upright and horizontal position during callusing recorded the highest sugars content in scion and rootstock. 
With respect to the interaction the data showed that pre-grafting incubation accompanied with horizontal position recorded the highest scion and rootstock value.

Generally scion contains more sugars, phenols and indoles than rootstocks. This is may be due to the more scion activity than rootstocks ad it may be helps more in scion break and building the grafting union.

TABLE 12. Effect of pre-grafting incubation and position of grafted materials aftercallusing on reducing sugars content of grafted 'Flame seedless' grapevines.

\begin{tabular}{|c|c|c|c|c|}
\hline \multirow{2}{*}{ pre-grafting } & \multicolumn{3}{|c|}{ Flame seedless scion mg/L FW } & \multirow{2}{*}{ Mean } \\
\hline & Horizontal & Upright & Upright down & \\
\hline no incubation & $354.0 \mathrm{c}$ & $287.9 \mathrm{c}$ & $435.7 \mathrm{ab}$ & 359.189 \\
\hline incubation & $314.9 \mathrm{c}$ & $456.8 \mathrm{a}$ & 361.7 bc & n.s. 377.822 \\
\hline Mean & $334.5 \mathrm{~B}$ & $372.4 \mathrm{AB}$ & 398.7 A & \\
\hline \multicolumn{5}{|c|}{ Salt creek rootstock } \\
\hline no incubation & $160.8 \mathrm{~d}$ & $182.0 \mathrm{~cd}$ & $265.2 \mathrm{bc}$ & 202.667 \\
\hline incubation & $222.2 \mathrm{~cd}$ & $355.5 \mathrm{a}$ & $320.4 \mathrm{ab}$ & $* * 299.4$ \\
\hline Mean & $191.5 \mathrm{~B}$ & $268.8 \mathrm{~A}$ & $292.8 \mathrm{~A}$ & \\
\hline
\end{tabular}

\section{Discussion}

The results showed that pre-grafting incubation together with upright incubation position during callusing processingincreased callus degree and percent which results in increasing scion bud break and rootstock rooting then grafting success), Since according to Rongting \& Pinghai (1993 scion moisture may be positively correlated with callus formation and growththese increases and the consequently grafting success can be explained by to their effect on grafts moisture. Its effect may be similar to those obtained by hot water treatments as soaking scion wood in water for $12 \mathrm{hr}$ prior to grafting ensures hydration of the plant tissues necessary for vigorous shoot growth and also, increased total sugars soluble sugars while decreased starch, total charbohydrates in some grapvine rootstocks (Phillips et al., 2015). positionposition

The positive effect of the upright position during callusing isin line with the obsevations of Zachej (1976) indicating that walnut trees should be positioned uprightly. This was mostly for practical reasons throughout the callusing period easier. Also, Porebski et al. (2002) developed a hot callussystem in Poland that was fixed on a glasshouse table in a uprightposition. Moreover, Exadaktylou et al. (2009) found that Cuttings placed vertically gave the best rooting percentage of Cherries cuttings compared to horizontal, Angle ad inverted position. Similar results reported by Tsipouridis et al. (2005). It may be for a correlation between polarity and both of root differentiation, and auxin movement (Hartmann et al., 2002). Moreover, Polarity reversal resulted in

Egypt. J. Hort. Vol. 43, No. 2 (2013) 
decreasing rooting percentage of hardwood cuttings of 'Kober 5BB' grapevine rootstock up to $60 \%$ (Cristoferi et al., 1988).

The reasons for their effects may be due to this is the right trend for sap water inside plant, stimulate and fasting growth of grafting material which may be shown on the higher number of sucker specially than the uprigh down position. This reflects in early induction of scion bud break with a good amount of rooting.due to a good and early connection between rootstocks and scion.

Increasing callus degree and percent (Tables 1 and 2) in grafting union helps more in increasing bud breaking percent as in Table 6 which may be considering an indicator for grafting success. Since, inflated buds of scion synthesize auxin and gibberellin hormones which accumulate at the cut injured surfaces of the graft union which activate cambium tissue for callus induction and formation beside accelerating differentiation and building transport tissues between scion and rootstock (Rongting and Pinghai, 1993).Callus tissue mostly comes from scion when the graft partners are of equal (Copes, 1969, Stoddard \& McCully, 1980 and Tiedemann, 1989). This may be explained that the more scion bud break associated with the formation and building of union grafting.

Movement of auxins is predominantly in basipetal direction (Bleasdale 1984, Rost et al., 1984 and Salisbury \& Ross 1992). As for the relationship between callus formation and rooting of grafted cuttings, the present results showed a positive correlation found between rooting and callusing in grafting cuttings. since stimulating rooting and suckering of rootstock stimulated callus formation and scion bud break subsequently grafting success (Arteca 1984 and Salisbury and Ross 1992).

The positive effect of the rootstock in the grafting success may be explained because of the rootstock has the ability to produce roots, suckers induced, grafting union and inducing scion bud break with a positive correlation between them during callusing period without competition which may be resposible for run out of rootstock growth promoters. So the highest rootstock stimulation the highest grafting success during callusing peiod.

In addition roots of rootstock may be acts as source of cytokines, which make a balance between it and exogenous auxins, applied for rootstock, for calluses induction (Nogueira, 2007).

The lower indoles content and the increase of phenol and sugars contents accompanied with higher grafting success in upright position with similar trend to pre-grafting can be explained by a depletion of reducing sugars, indoles concomitant with the increase of reducing sugars and phenols compounds in the growth processes of root formation, callus formation and start of bud break and growth either in scion or rootstock. Also, the grafting success may depend on the balance between indoles, phenols and sugars. 
Furthermore, the effect of phenolic compound on rooting is complicated and varying according to the concentration, phenols type and rooting stage. Low phenolic concentrations may stimulate adventitious root formation and grafting success (Stino et al., 2011), while higher concentrations may restrict them (Wilson and Van Staden 1990). On the other hand, Somkuwar et al. (2011) reported that high levels of phenols in grape rootstock cuttings at planting may be correlated with the formation of root primordia and stimulate the elongation of the roots. With respect to the phenols type, some phenolic compounds had a positive effect such as phloroglucinol and chlorogenic acid on rooting (Wilson and Van Staden, 1990, Wang 1991 and Shiozaki et al., 2013). Also, gallocatechin found in 'Campbell Early' cuttings which may be prevent IAA oxidation. Moreover, Catechin and gallocatechin had a positive effect due to prevent peroxidase-catalyzed auxin oxidation (Osterc et al., 2008)

\section{Conclusion}

From this study, it can be concluded that there is no antagonistic effect between formation of rooting and grafting unionin grape grafted cuttings, since upright position recorded the highest callus percent and degree together with the highestrooting percent. Also, the upright positionsurpassed pre-grafting incubation in increasinggrape grafted cuttings success.

\section{References}

Achim, G. and Botu, I. (2001) Results in walnut propagation by using different methods. Acta Hort., 544, 503-509.

Arteca, R.N. (1984) "Plant Physiology in Relation to Horticulture", Macmillan Press. London, 144p.

Bleasdale, J.K.A. (1984) "Principles of Plant Physiology", San Francisco, W.H. Freeman \& Company, 143p.

Copes, D.L. (1969) Graft union formation in Douglas-fir. Amer. J. Bot., 56, $285-89$.

Cristoferi, G., Filiti, N.and Rossi, F. (1988) The effects of reversed polarity and acropetal centrifugation on the rooting of hardwood cuttings of grapevine rootstock Kober 5BB. Acta Hort., 227, 150-154.

Diab, Y.A.A., Mousa, M.A.A., Warnock, D.F. and Hahn, D.E. (2009) Opportunities for Producing Table Grapes in Egypt for the Export Market: A Decision Case Study. International Food and Agribusiness Management Review, 12 (2), 57-70.

Dubois, M., Gilles, K.A., Hamilton, J.K., Rebers, P.A. and Smith, F. (1956) Colorimetric Method for Determination of Sugars and Related Substances. Anal. Chem., 28 (3), 350-356.

Duncan, D.B. (1955) Multiple Range and Multiple F-Tests. Biometrics, 11, 1-42.

Egypt. J. Hort. Vol. 43, No. 2 (2013) 
Erdogan, V. (2006) Use of callusing cable in walnut propagation. Acta Hort., 705, 313317.

Exadaktylou, E., Thomidis, T., Grout, B., Zakynthinos, G. and Tsipouridis, C. (2009) Methods to Improve the Rooting of Hardwood Cuttings of the 'Gisela 5' Cherry Rootstock. Hort Tech., 19 (2), 254-259.

FAO (2016) Food and Agriculture organization http://faostat3.fao.org/download/Q/QC/E

Ferhato, G.L.Y. (1997) The studies on the effect of potting and omega grafting in relation to different time on graft taking percents of some standard walnut varieties. Acta Hort., 442, 303-308.

Freed, R., Eisensmith, S.P., Goetz, S., Reicosky, D., Smail, V.M. and Wollberg, P. (1990) MSTAT-C A Microcomputer Program for the Design, Management and Analysis of Agronomic Research Experiments. https://www.msu.edu/ freed/disks.htm

Halbrooks, M.C. (1985) Rapid and high volume grafting for florida viticulture. Proc. Fla. Strife IforL Sor., 98, 170-172.

Hartmann, H.T., Kester, D.E., Davies, F.T. and Geneve, R.L. (2002) Hartmann and Kesters' plant propagation: Principles and Practices. $7^{\text {th }}$ ed., Prentice Hall, Upper Saddle River, NJ.

Hegazi, A. and Omar, A.H. (2000) Selection of grape varieties for high quality and export purposes. Acta Hortic., 528, 673-676

Hunter, J.J., Volschenk, C., Le Roux, D. J., Fouché, G. W. and Adams, L. (2002) Plant material quality A compilation of research.ARC Infruitec-Nietvoorbij, Private Bag X5026, 7599 Stellenbosch, South Africa, 1-18

Kamiloglu, O. and Tangolar, S. (1997) A comparison of three methods producing grafted vines. Procedings of the Fifth International Symposium on Temperate Zone Fruits in the Tropics and Suptropics, pp. 395-398.

Kose, C. and Guleryuz, M. (2006) Effects of auxins and cytokinins on graft union of grapevine (Vitisvinifera). New Zeal J Crop Hort., 34, 145-150.

Lantos, A. (1990) Bench grafting walnuts. Acta Hort., 284, 53-56.

Larsen, P., Harbo, A., Klungson, S. and Ashein, T.A. (1962) On the biogenesis of some indole compounds in Acetobacterxylinum. Physiol. Plant, 15, 552-565.

Mckenry, M.V. and Anwar, S.A. (2006) Nematode and Grape Rootstock Interactions Including an ImprovedUnderstanding of Tolerance. J. Nematol, 38, 3: 312-318.

Nogueira, R.C. (2007) Indução de calosemexplantesfoliares de murici-pequeno (Byrsonimaintermedia A. Juss.). Ciência e Agrotecnologia, Lavras, 31 (2), 366-370. 
Osterc, G.M., "Stefancǐc, S.A. and `Stampar, F. (2008) "Phenolic content in cuttings of two clones of hybrid chestnut (Castanea crenata x Castanea sativa) in the first days after cutting severance," Acta Agr., Sc and B, 58 (2), 162-168.

Ozkan, Y. and Gümüs, A. (2001) Effects of different applications on grafting under controlled conditions of walnut (Juglans regia L.). Acta Hort., 544, 515-520.

Ozkaya, M.T. and Celik, M. (1999) Qualitative analysis of phenolic compounds in olive cuttings. Acta Hort., 474, 477-480.

Paunovic, S.A.M., Miletic, R., Mitrovic, M. and Ankovic, D.J. (2011) Effect of callusing conditions on grafting Success in walnut (Juglans regia 1.). J. Fruit Orn. Plant Res., 19 (2), 5-14.

Phillips, N., Reynolds, A. and Profi, F.D. (2015) Nonstructural Carbohydrate Concentrations in Dormant Grapevine Scion wood and Rootstock Impact Propagation Success and Vine Growth. Hort. Technology, 25 (4), 536-550.

Porebski, S.,Rzeź, N. B. and Poniedzialek, W. (2002) Comparison of two methods of walnut grafting. J. Fruit Orn. Plant Res., 10, 55-62.

Qaddoury, A. and Amssa, M. (2004) Effect of exogenous indole butyric acid on root formation and peroxidase and indole-3-acetic acid oxidase activities and phenolic contents in date palm offshoots. Bot Bull Acad Sin 45, 127-131.

Rongting, X. and Pinghai, D. (1990) Theory and practice of walnut grafting. Acta Hort 284, 69-88.

Rongting, X. and D. Pinghai (1993) A study on the uniting process of walnut grafting and the factors affecting. Acta Hort., 311, 160-172.

Rost, T.L., Barbour, M.G., Thornton, R.M., Wiever, T.E. and Stocking, C.R. (1984) Botany. NewYork, Wiley \& Sons., 342p.

Salisbury, F.B. and Ross, C.W. (1992) "Plant Physiol.", California, Wadsworth Publishing Comp. 682 p.

Shiozaki, S., Makibuchi, M. and Ogata, T. (2013) Indole-3-Acetic Acid, Polyamines, and Phenols in Hardwood Cuttings of Recalcitrant-to-Root Wild Grapes Native to East Asia: Vitis davidii and Vitis kiusiana. Journal of Botany, Article ID 819531, 9 p.

Singleton, V.L., Orthofer, R. and Lamuela-Raventos, R.M. (1999) Analysis of total phenols and other oxidation substrates and antioxidants by means of Folin-Ciocalteu reagent. In: "Oxidants and Antioxidants", Part A., PACKER, L. (Ed.). New York, Elsevier, pp. 152-178.

Snedecor, G.W. and Cochran, W.G. (1989) "Statistical Methods", $8^{\text {th }}$ ed., Ames, Iowa State University Press, Iowa.

Egypt. J. Hort. Vol. 43, No. 2 (2013) 
Somkuwar, R. G., Bondage, D.D., Surange, M. S. and Ramteke, S. D. (2011)“Rooting behaviour, polyphenol oxidase activity, and biochemical changes in grape rootstocks at different growth stages," Turk. J. Agric. For., 35 (3), 281-287.

Stino, R.G., Ghoneim, I.E., Morwad, I.A. and Fadl, T.R. (2011) Performance of summer grafted superior seedless grape grafts on different rootstocks. Journal of Horticultural Science \& Ornamental Plants (JHSOP), 3 (1), 86-90.

Stoddard, F.L. and McCully, M.E. (1980) Effects of excision of stock and scion organs on the formation of the graft union in coleus: A histological study, Bot. Gaz, 141, $401-412$.

Tiedemann, R. (1989) Graft union development and symplastic phloem contact in the heterograft Cucumissativus on cucurbitaficifolia. J. Plant, Physiol., 134, 427-40.

Tsipouridis, C., Thomidis, T. and Michailides, Z. (2005) Influence of some external factors on the rooting of GF677 peach and nectarine shoot hardwood cuttings. Aust. J. Exp. Agr., 45, 107-113.

Vrsic, S., Pulkoa, B. and Kocsis, L. (2015) Factors influencing grafting success and compatibility of grape rootstocks. Sci. Hort., 181, 168-173

Walker, R.R., Blackmore, D.H., Clingeleffer, P.R. and Iacono, F. (1997) Effect of salinity and Ramsey rootstock on ion concentrations and carbon dioxide assimilation in leaves of drip-irrigated, field-grown grapevines (Vitis vinifera L. cv. Sultana). Aust. J. Grape, Wine, Res., 3, 66-74.

Wang, Q. (1991) "Factors affecting rooting of microcuttings of the pear rootstock BP10030," Sci. Hortic, 45 (3-4), 209-213.

Wilson, P.J. and Van Staden, J. (1990) "Rhizocaline, rooting co-factors, and the concept of promoters and inhibitors of adventitious rooting-a review," Ann BotLONDON, 66 (4), 479-490.

Zachej, S. (1976) Determination of the optimum time for grafting walnuts with the use of heat. Hort. Abstr., 46 (10), 780.

(Received 27/7/2016;

accepted 26/10/2016) 


\section{تأثير التحضين قبل التطعيم وإتجاه العقل المطعومة على نسب نجاح

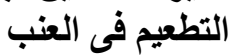

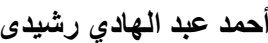
قسم الفاكهة ـ كلية الزر اعثة ــ جامعة القاهرة ـ القاهرة - مصر.

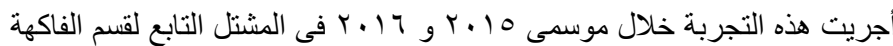

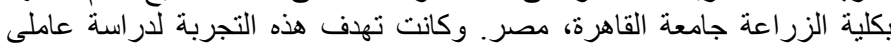

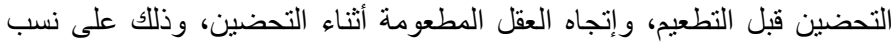
نجاح تطعيم صنف العنب الفليم سيدليس (Falme Seedless) على أصلى الصل السولت التبلت

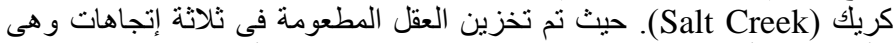

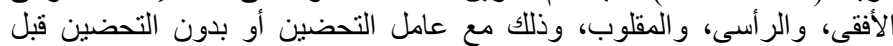

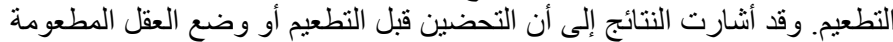

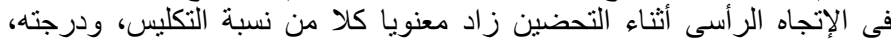

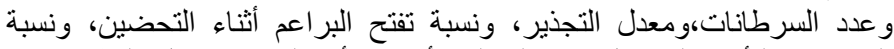

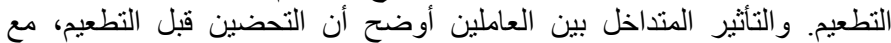

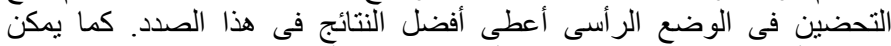

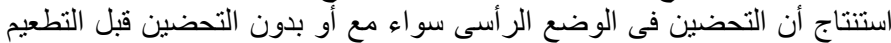

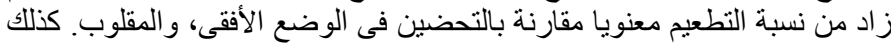

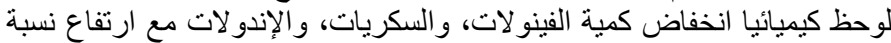

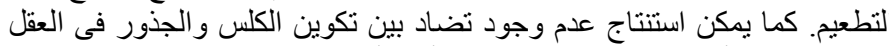

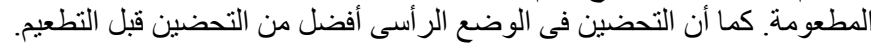

